\title{
Potentials of the Groundnut Sector towards Achieving Food Security in Senegal
}

\author{
Ndiaye Georges $^{1 *}$, Shaoyong Fang ${ }^{1}$, Mukete Beckline ${ }^{2}$, Ye Wu ${ }^{1}$ \\ ${ }^{1}$ School of Economics and Management, Beijing Forestry University, Beijing, China \\ ${ }^{2}$ School of Forestry, Beijing Forestry University, Beijing, China \\ Email: ^georges0144@yahoo.com, seanwork@126.com, munasawa@gmail.com,332634108@qq.com
}

How to cite this paper: Georges, N., Fang, S.Y., Beckline, M. and Wu, Y. (2016) Potentials of the Groundnut Sector towards Achieving Food Security in Senegal. Open Access Library Journal, 3: e2991.

http://dx.doi.org/10.4236/oalib.1102991

Received: August 19, 2016

Accepted: September 2, 2016

Published: September 5, 2016

Copyright $\odot 2016$ by authors and Open Access Library Inc.

This work is licensed under the Creative

Commons Attribution International

License (CC BY 4.0).

http://creativecommons.org/licenses/by/4.0/

\begin{abstract}
In this paper, we assess the potentials of the groundnut producing sector in Senegal. The paper also identifies possible strategies to implement in order to fully benefit from this sector and its role in achieving food security. A comprehensive scientific literature review was carried out to ascertain the unexploited potentials of this sector. Using this approach, we found out that several unexploited potentials existed along the value chain of the groundnut sector. These potentials range from inputs through procurement and to the marketing of finished products. We also observed that complete exploitation of these potentials would sustainably and enormously contribute to the growth of the groundnut sector, improve rural livelihoods and achieve food security.
\end{abstract}

\section{Subject Areas}

Agricultural Science, Business Finance and Investment, Development Economics, Economic System, Environmental Economics, Food Science \& Technology, Natural Geography, Socioeconomics

\section{Keywords}

Groundnut Sector, Agriculture in Senegal, Food Security, Rural Livelihoods, Economic Growth, Poverty Alleviation

\section{Introduction}

Over the past decades, food security has been a major global challenge especially in less developed countries [1]-[4] where over 1 billion people are estimated to suffer from the lack of sufficient dietary energy availability and over 2 billion people are affected by the lack of micronutrients [2]-[5]. Global food security is achieved when all people at all 
times have access to adequate affordable, safe and nutritious food to meet all their dietary requirements and food preferences so they can live a productive and healthy life [3] [4] [6] [7].

Senegal lies along the coast of northwest Africa with an estimated population of about 15 million inhabitants [8] [9]. It has a tropical climate with a dry season from November to May, and a rainy season from June to October. The dry season is dominated by the hot and dry Harmattan wind around Dakar (the capital city) with average maximum temperatures of $30^{\circ} \mathrm{C}$ and average minimum temperatures of $24.2^{\circ} \mathrm{C}$. Between December and February at the peak of the dry season, maximum temperatures average $25.7^{\circ} \mathrm{C}$ and minimums $18^{\circ} \mathrm{C}$ [10]. Interior temperatures are higher than along the coast (for example, average daily temperatures in Kaolack and Tambacounda for May are $30^{\circ} \mathrm{C}$ and $32.7^{\circ} \mathrm{C}$ respectively, compared to Dakar's $23.2^{\circ} \mathrm{C}$. In Tambacounda in the far interior, especially along the Malian border where desert begins, temperatures can reach as high as $54^{\circ} \mathrm{C}$. Generally speaking, the country is mostly very sunny and dry with average annual rainfall varying between $600 \mathrm{~mm}$ from the north in the Sahel to $1500 \mathrm{~mm}$ in the south along the West African coast.

Consequently, the landscape varies considerably, being semi-desert in the north, while the south is occupied by the savanna, and with gallery forests along the rivers. Therefore, Senegal's northernmost part has a near hot desert climate, the central part has a hot semi-arid climate and the southernmost part has a tropical wet and dry climate. It is estimated that about $57 \%$ of this population lives in rural areas with agriculture being their major occupation. These rural areas of Senegal, due to over dependence on rain-fed agriculture and low household income face food security issues. These issues are also partly due to the effects of macro-economic shocks such as fiscal adjustments and monetary policy reforms and probably climate variations [8]. Apart from the lack of adequate income sources and resources for better livelihoods, these rural communities also face other challenges such as hunger, malnutrition, lack of access to basic education, adequate healthcare facilities and involvement in the decision-making process [11].

Also referred to as peanuts, groundnuts Arachis hypogaea are basically found in four different product categories including; groundnuts in shell, shelled groundnuts, groundnut oil and groundnut cakes [12] [13]. These range from food products (peanut butter, biscuits, cooking oil); household use (paint, varnish, fuel); agricultural inputs (insecticides, fertilizers, animal feed, nitroglycerin); beauty (soap, cosmetics); building material (plastics, wallboards, abrasives) and cellulose (rayon, paper) [13]. Sustainable economic growth and prosperity is necessary for poverty alleviation and food security gains. Therefore, the groundnut production sector may serve as an effective avenue for income generation and job creation. Most especially in the Groundnut Basin where about 70\% of the local population makes a living through groundnut farming accounting for over $35 \%$ of their household revenue [14]. Groundnuts also constitute an important component part of local staple foods in Senegal with an estimated monthly household consumption of about 30 liters of groundnut oil. 
For instance, although other groundnut dishes exist, Mafe a peanut butter stew served on white rice is among the most prized culinary delicacies of the Senegalese cuisine. Grinded groundnuts are also used in other recipes such as Bassé which is a Senegalese dish usually prepared during the Muslim New Year festival. This dish is made from groundnut powder, millet, beans, meat and some other ingredients. In addition, other groundnut dishes include Mbakhal Saloum, which is made of rice and dried seafood, and Thiéré Mboum, which is a traditional millet-based recipe that originated from farmers of the Sérère ethnic group who make up over $15 \%$ of the Senegalese population. Apart from these dishes, an important part of edible groundnuts are transformed into snacks, such as Guerté Thiaff (roasted peanuts) and Guerté Sukar (dry peanuts and sugar) as well as groundnut nougat.

At the macro level, proceeds from groundnut exports in Senegal are used to finance food imports, especially cereal imports such as rice and wheat. Besides this vital economic role, groundnuts are an important part of the culture and ways of life in Senegal either in terms of migratory cycles, labour specialization or culinary tastes [13].

However, since the 1970s, groundnut production has decreased with the earning potential of groundnut exports from Senegal being significantly reduced. This is often attributed to falling world prices, poor weather conditions, domestic and international economic shocks coupled with the emergence of substitutes [13] [15]. Nonetheless, the groundnut sector in Senegal still has a lot of potentials that could be exploited in order to generate more revenue, decrease the seasonality of jobs in the Groundnut Basin, create more jobs, and to alleviate poverty in rural areas [14]. For instance, Cabral [16] espoused that the probability of food security in Senegal is significantly low for farmers who have access to sufficient agricultural pastoral goods.

This research is relevant to policy makers because since the 1970 s, the groundnut sector has been crisis ridden. Despite all the efforts made in sustaining production, it is yet to achieve the desired optimum growth especially as a few sectors still remain largely under-developed. It is hoped that this paper will assist policy makers and decision taker in fully exploiting the potentials of the groundnut sector. This will especially provide policy-making basis for the government while also contributing to unveiling the other income-generating activities of this sector. Benefits that could be derived from a full-scale exploitation of groundnuts in Senegal include increased income, employment generation, improved standard of living and better livelihood for rural communities.

In this study, we carry out a literature review to assess how the potentials of the Senegalese groundnut sector could be tapped into so as to improve the livelihood of rural communities. This paper is divided into three sections with the first looking at the contribution of the groundnut sector to the national economy. Specifically, we describe how groundnut farming has impacted the Senegalese economy since the 1960s. In the second section, we stress the challenges that are currently facing this industry and that are hindering its growth. The third and last section highlights the potentials of this industry and the ways in which they could be exploited to achieve food security in rural areas. 


\section{Groundnut Sector in Senegal}

The agricultural sector in general, has a multiplier effect on the socio-economic and industrial fabric of any nation because of its multifunctional nature [17] [18]. Agriculture is the mainstay of many economies playing a fundamental role in their socio-economic development [18]. In Senegal for instance, it plays an important role in the economy accounting for over 17\% of the Gross Domestic Product (GDP). Agriculture is mainly rain-fed and depends heavily upon the seasonal rainfall amounts and distribution. Food staples such as millet, sorghum, maize, and rice are grown for domestic consumption while cotton and groundnut are grown for export.

Among the major cultivated crops, groundnuts topped the production chart accounting for over $60 \%$ of the agricultural GDP in the 1960s [19]. The sector also employed over $70 \%$ of the population, generating about $35 \%$ of the annual household income [14]. Groundnuts are cultivated throughout Senegal with major growing areas being Kaolack, Fatick, Thiés, Diourbel and Louga which are all located within the Groundnut Basin [20]. The Groundnut Basin is located in the Midwest of Senegal covering an estimated area of about $51,315 \mathrm{~km}^{2}$. The area covers about a third of Senegal's arable land employing almost two thirds of the agricultural population [21] [22]. In addition, groundnuts were the first crop which permitted the shift from manual to animal traction farming techniques in West Africa [22].

During 1960s, groundnuts were the traditional and industrial cash crops that played a major economic role in rural areas, representing over $80 \%$ of the country's exports, covering about half of the cultivated area, and employing $87 \%$ of the active population [23]-[25]. Over the years, groundnut farming became the sole agricultural activity through which rural populations could earn a reasonable income. It also constituted the main source of raw materials for oil processing industries [23] [26]. In 2005, more than 250,000 tons of groundnuts were harvested and sold to local processing industries that produced over 80,000 tons of oil. About 75,000 tons of this oil was exported ranking Senegal as the first crude groundnut oil exporting country in the world. These exports accounted for over USD 90 million in export revenues [14] see, Figure 1.

As illustrated in Figure 1, groundnuts play an important role in GDP growth and although exports alone cannot explain GDP growth, we can still see a similarity in the trends of real GDP growth rate and groundnut oil exports. Figure 1 illustrates that groundnut oil exports reached a peak value of 112,876 tons in 2001 and a lowest value of 12,255 tons in 2008. The 1994 devaluation of the local currency, the CFA Franc coupled with a large-scale privatization campaign and trade liberalization policies may have contributed to this surge of exports in the early 2000s. Between 2000 and 2001, groundnut harvest was estimated at over 1 million tons, a record level since the 1970s. Here, the Société Nationale de Commercialisation des Oléagineux du Sénégal (SONA$\mathrm{COS}$ ), the former state-owned groundnut processing company had been offering higher producer prices, $145 \mathrm{CFA} / \mathrm{kg}$ compared to world prices of $136 \mathrm{CFA} / \mathrm{kg}$, in order to stimulate output. In 2008, groundnut production fell by over $47 \%$ due maybe to a fall in groundnut oil prices in Europe (major importer), persistent drought and soil degrada- 
tion, which significantly affected production.

As to GDP, its growth rate hit a highest level of $6.1 \%$ in 2005 and a lowest value of $1.8 \%$ in 2008. These GDP trends maybe related to macroeconomic factors such as household consumption, investment, government expenditure and net exports. The fact that net exports are calculated by subtracting imports from exports, this implies that the greater the exports, the greater the net exports. Therefore, an increase or decrease in groundnut oil exports results in an increase or decrease in GDP. Therefore, changes in GDP growth rate can be partially attributed to the trends in groundnut oil exports, which are one of the main foreign exchange earning activities in Senegal.

It can be deduced from Table 1 that, groundnut oil is the most traded among all groundnut products traded in international markets.

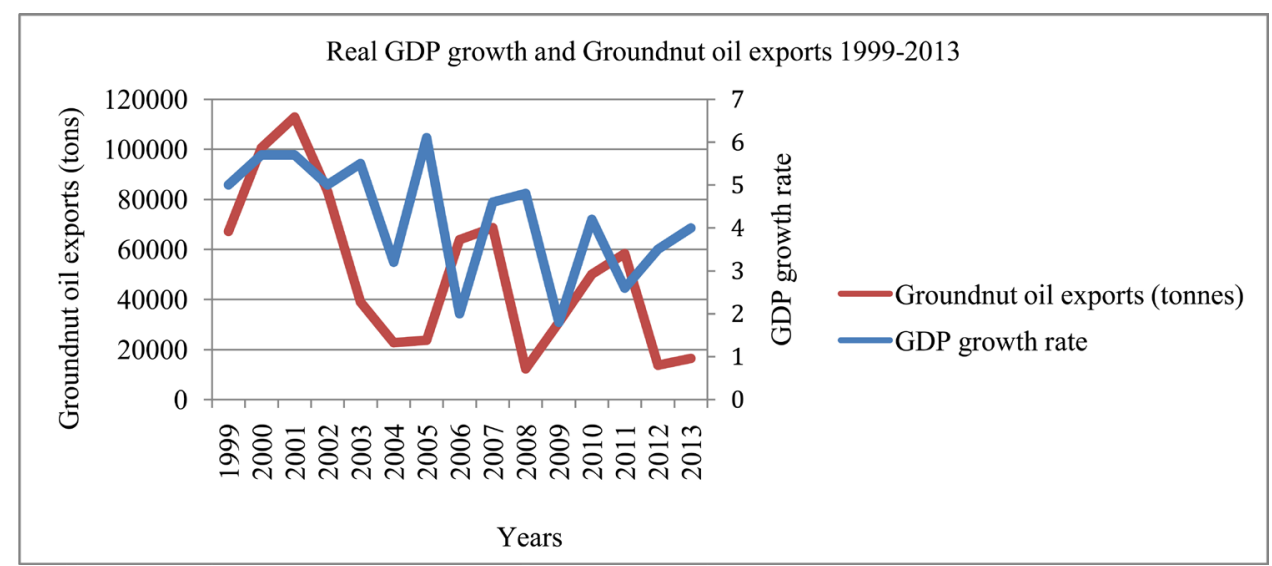

Figure 1. Trends of Real GDP growth and Groundnut oil exports 1999-2013 (Source: CIA, 2015; FAOSTAT, 2016).

Table 1. The value of net global exports by groundnut products between 1996 and 2000: Source: FAOSTAT, 2002.

\begin{tabular}{ccccc}
\hline & Edible Groundnut & Groundnut Oil & Prepared Groundnut & Total \\
\hline China & 193.79 & 2.82 & 111.06 & 307.68 \\
India & 86.85 & 0.13 & 7.27 & 93.99 \\
USA & 126.43 & -12.77 & 28.26 & 141.92 \\
Argentina & 160.98 & 51.52 & 25.82 & 238.32 \\
Nigeria & -3.29 & 4.64 & 0.00 & 1.35 \\
Senegal & 3.34 & 48.99 & 0.60 & 52.92 \\
South Africa & 16.01 & 4.68 & 0.27 & 20.95 \\
Malawi & 0.77 & 0.00 & 0.00 & 0.77 \\
Gambia & 4.49 & 1.09 & 0.05 & 5.63 \\
EU (15) & -378.47 & -115.12 & -4.54 & -498.13 \\
Canada & -76.67 & -1.19 & -3.31 & -81.18 \\
Japan & -44.00 & -1.85 & -71.46 & -117.31 \\
Korea & -4.55 & 0.01 & -14.31 & -18.86 \\
\hline
\end{tabular}


Groundnuts are ranked $6^{\text {th }}$ among the main oilseeds that are grown worldwide with Senegal as one of the world's leading exporters [15] [27]. For instance, between 1996 and 2000 Senegal was the largest African exporter registering a USD 53 million groundnut trade surplus with $92 \%$ of this net export being groundnut oil. But according to [28], China and India produce over $60 \%$ of world groundnuts while Africa accounts for $25 \%$ of the overall production with Nigeria, Senegal, Sudan, and Niger being the main exporters.

The production of groundnut and exports drove economic growth in Senegal in the 1960s supplying over $23 \%$ of the world exports, thus spurring rapid economic growth. These exports were estimated at about USD 50 million per year [29] [30]. Between 1959 and 1965, increases in annual incomes of Senegalese groundnut producers amounted to $6 \%$ annum that is increasing from 830,000 tons to over $1,170,000$ tons during the same period. This remarkable growth was lead by an extension of cultivated areas and higher yields returns [13]. Similarly and according to [31], groundnut exports drove Senegal's economy, as "this crop used an increasing share (more than one-half) of the national cultivated area in an ecological zone subject to recurring drought cycles", and accounting for about $78 \%$ of all exports.

However, the breakdown of the West African Federation (AOF) in the 1960s nevertheless decelerated peanut production and industrial development in Senegal, as markets shrank from 20 million to 6 million of consumers, driving up operating costs [13]. Investment fell from $13.6 \%$ of the GDP to $3.8 \%$ in the same period [29]. Groundnut exports previously estimated at about $79 \%$ of import expenditures dwindled, while rapid population growth at $2.1 \%$ on average offset the already slow average GDP growth of $2.8 \%$ bringing forth problems and challenges for the groundnut sector.

\section{Challenges Facing the Groundnut Sector in Senegal}

As shown in Figure 2, groundnut production in Senegal fell from 1,444,093 tons in 1975 to about 260,723 tons in 2004. It rose again to over 527,528 tons in 2011 and attained 677,456 tons in 2014. This trend is similar to that of the cultivated area, which fell from 1,500,000 hectares (ha) in 1975 to about 524,843 ha in 2004 [15]. However, edible groundnut production grew steadily from 1995 to 2004 with an annual average of 40,000 tons as a result of the opening of new markets [32].

In recent times, Senegal's annual groundnut production is far behind China's with 6 million tons planted over 3.6 million ha, India's whose production is about 5.6 million tons cultivated across an estimated 8 million ha and the USA's, Nigeria's and Argentine's who jointly produce between $1-1.5$ million tons [26]. These groundnut exports from Senegal are less than $4 \%$ of total exports and lesser than the $80 \%$ exported during the 1960s [26]. For example, during the 2012 financial year, processed groundnut exports accounted for only $1.3 \%$ of the country's GDP. These statistics reflect the crisis affecting the groundnut sector for decades which may be related to seeds procurement and supply of cultivated grains.

Figure 2 depicts the trends in production tonnage and shows how these have been 
fluctuating through the years. This underperformance of the groundnut sector in recent times is may often be attributed to ecological, social and economic factors.

\subsection{Ecological Factors}

These ecological factors may include but not limited to rainfall variability, soil degradation and recurrent droughts, see Figure 3. Groundnut production is subject to drought and threats from pests such as desert locusts (Schistocerca gregaria). The north of Senegal is characterized by greater rainfall variability, the least diversified rain-fed agriculture with widespread herding that is relatively more important than crop produc-

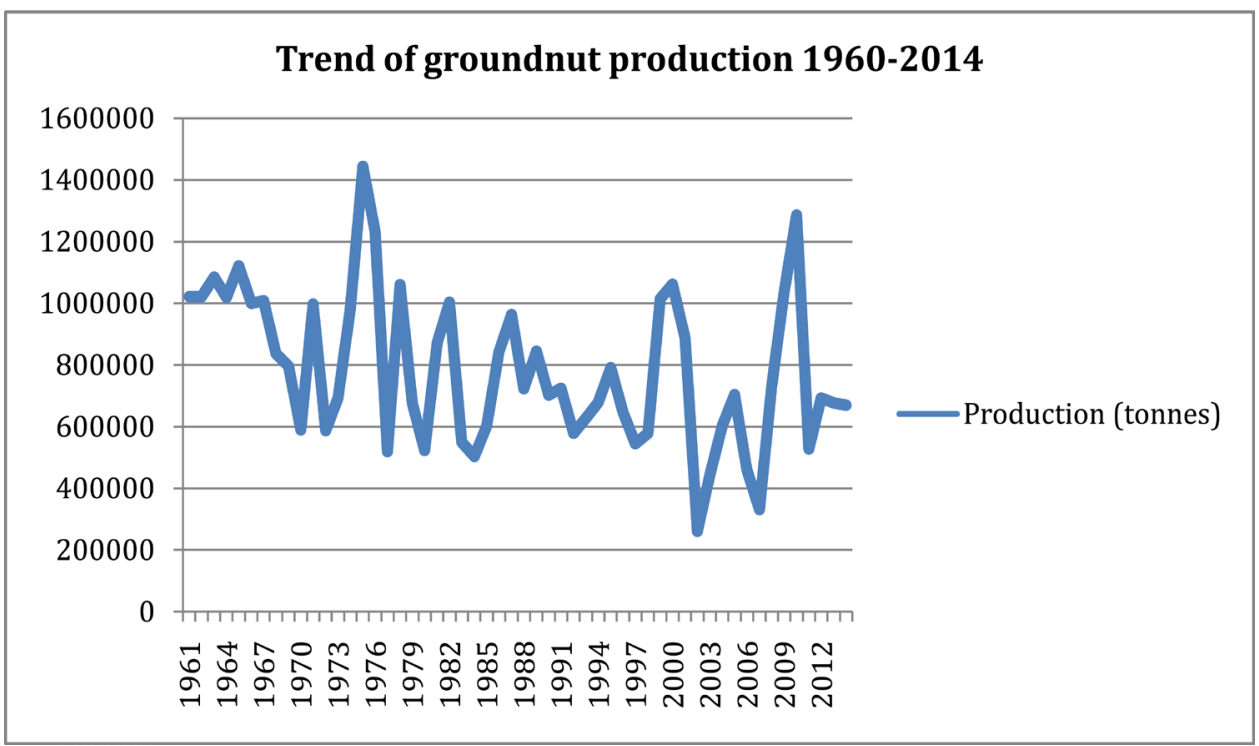

Figure 2. Groundnut production in Senegal between 1960 and 2014. Source: FAOSTAT, 2016.

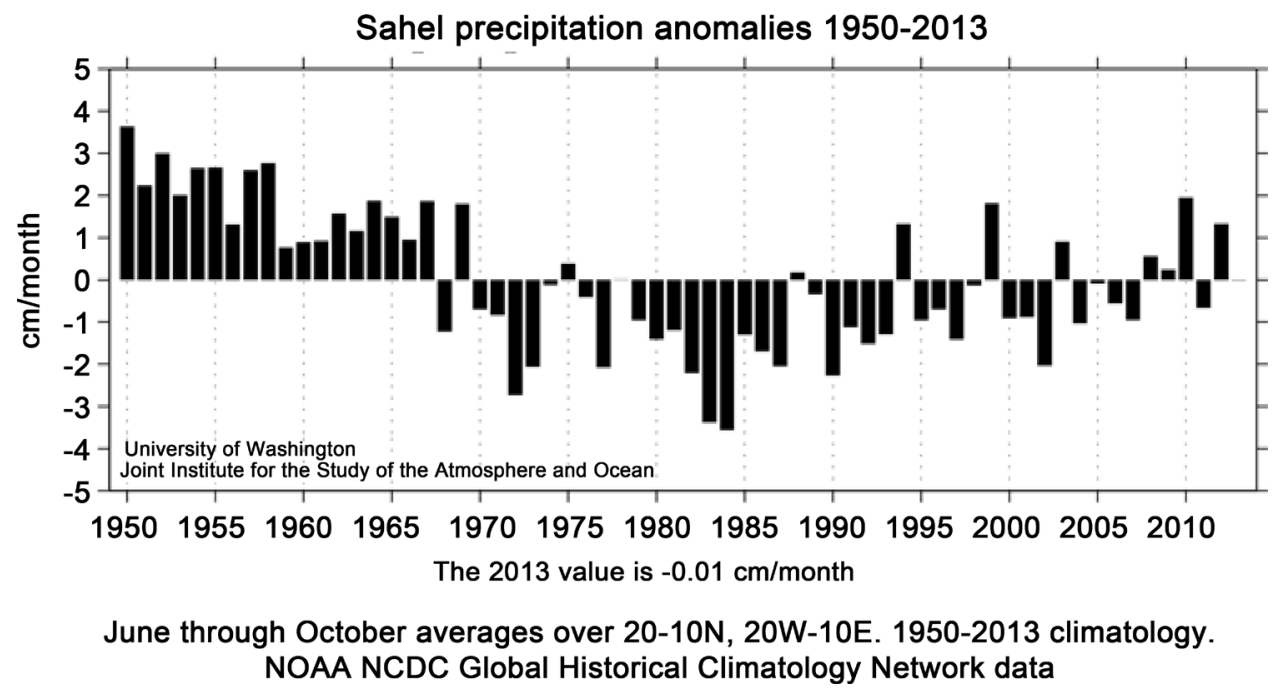

Figure 3. Sahel Precipitation Index (20-10N, 20W-10E), 1900-May 2015, the averages are taken of NOAA Global Historical Climatology Network gridded rain gauge precipitation anomalies. The averaging region was chosen from a rotated principal component analysis of African precipitation [43]. 
tion. This region is the most affected by drought and has a population which is more and often exposed to food insecurity [33].

Rainfall in Senegal declined rapidly between 1950 and the mid-1980s, and partially recovered in the 1990s although the 2000-2009 mean remained about 15\% lower than that of 1920-1969 [34]. These changes in rainfall can be visualized as a reduction of the areas receiving adequate rainfall for viable agricultural livelihoods. It mostly rains in Senegal between June and September, typically providing just sufficient water for crops and livestock [33]. Between 1960 and 1989, the number of regions receiving (on average) this much rain during June-September have receded mostly southward by about 30 kilometers. This retreat has likely affected the important crop growing regions near the cities of Thies and Diourbel, an important peanut growing region. Meanwhile around the western regions, this trend in rainfall coincides with the densely populated regions of Thies, Diourbel, and Kaolack. Observed changes (those occurring between 1960 and 2009) account for $63 \%$ of the change magnitudes.

Since 1975 , average annual temperatures have increased by almost $0.9^{\circ}$ Celsius $\left({ }^{\circ} \mathrm{C}\right)$ across much of Senegal [33] [35]. This transition to an even warmer climate may have reduced crop harvests and pasture availability, thus amplifying the impact of droughts. In addition, such warming in regions with very high average air temperatures, can amplify the impact of water shortages.

\subsection{Social Factors}

The social factors affecting groundnut production may include but not limited to population trends, dilapidated machinery, lack of incentives for farmers, and disorganization of the sector. Looking at rainfall, though its increase from the 1980s to 1990s helped improve yields, these yield increases may have been offset by large declines in the amount of farmland per person. The rapid population expansion in Thies, Diourbel and Kaolack which are heavily populated regions important for peanut production, combined with further drying and warming, could lead to increased food insecurity in these areas. Moreso, in 2011, Senegal's population was estimated at about 13 million with a growth rate of $2.5 \%$. This implies that, it is possible for the population to double every 27 years [36]. Furthermore, between 1990 and 2010, the nation's population witnessed a $64 \%$ increase thus increasing stress on limited natural resources. Analysis of crop statistics from the Food and Agriculture Organization of the United Nations [37] suggests that increases in crop yields have not kept pace with population growth. Between the 1960s and 2000s, the amount of farmland per person has declined by $300 \%$ (from 0.3 ha per person to 0.1 ha per person), while yields have only increased by $70 \%$. Therefore if such trends continue, these will be unfavorable for national food security especially as projections for 2025 based on these trends suggest that Senegal will pro-

duce $30 \%$ less cereal crops per person. Another potential risk is sea-level rise which at present has resulted in coastal retreats of about 1 - 2 meters annually in Senegal [38]. Further evidence highlights that salinization has increased especially in the groundnut basin as a result of drought and sea-level rise. Therefore, continued sea-level rise could 
result in further deterioration of soil quality and erosion along the sandy coastlines [39] [40].

\subsection{Economic and Technological Factors}

Other economic and technological factors may include; low use of agricultural inputs including certified seeds, fertilizers, pesticides, etc., poor seeds, lack of access to finance, absence of transformation industries, presence of aflatoxin as well as competition from other oilseeds such as palm oil, soybean, coconut and sunflower. Among the abovementioned factors, the discovery of the poisonous substance, aflatoxin produced by the saprotrophic and pathogenic fungi species Aspergillus flavus in groundnuts, negatively affected Senegalese exports in the early 1980s [41]. In addition, recent scientific evidence espoused that, the presence of high levels of aflatoxin could induce mycotoxicosis, hence leading to cancer [42].

Due to these aflatoxins, major importers of Senegalese groundnuts within the European Union as well as Asia and North America turned to other producers in Latin America and South Asian. These countries have the competitive advantage of a stable weather and better yielding varieties [13] [41].

Despite all these major challenges, the groundnut sector in Senegal has potentials that, if adequately exploited, could contribute to its growth and the fulfillment of its core functions of ensuring food security in rural areas via revenue generation and job creation.

\section{Potentials of the Groundnut Sector to Tackle Food Security Issues}

Groundnuts are the fourth revenue earning exports in Senegal after fishing, phosphates, and the tourism industry [20]. The groundnut sector plays a vital role in the economic growth of Senegal where it is the main income source for many rural household farmers and an important component of their daily diet. Due to the diverse nature of activities attributed to the groundnut sector, the different activities could be harnessed. This harnessing could aid in resolving the current production setbacks and tackle food security challenges that threaten rural livelihoods.

The provision of inputs is an important activity for the groundnut sector. This is because, the need to produce upgraded seeds, manufacture new agricultural machinery and repair old ones has become more imperative [15] [44] [45]. Such needs can be met since locally cultivated seeds are available with a wider opportunity to increase and diversify revenues as well as create new jobs. These could be more feasible through the financing of both producers and buyers while providing them with pre-basic seeds. Moreso, granting appropriate financial access to local manufacturers of agricultural machinery would serve as a booster for the groundnut sector.

Similarly, the production and sale of edible groundnuts and oil cakes are major potential sectors that could be improved. This is because most of the groundnut products exported from Senegal is in the form of oil. This therefore reiterates the fact that, edible 
groundnuts and oil cakes account for a negligible component of export products. This is very obvious since the potential for growth in this sector is still very huge and could be harnessed to increase productivity. Edible groundnuts could also be massively produced since they are high in demand domestically and internationally. The second livestock feed in the European Union is composed of oil cakes, making it a potential source of revenue for Senegal [14]. Moreover, oil cakes are easy to conserve with longer shelf lives hence can be retailed for longer periods even up to years. Capacity building and training of farmers on how to control aflatoxin and use of detoxifying equipment could also boost production, create new jobs and increase rural income.

Oil is the main product that results from groundnut processing in Senegal although other products such as peanut paste, peanut butter and soap are also produced. This means that, there is still room for a more diversified groundnut processing industry in Senegal [15]. At the same time, handcrafted trituration techniques should also be promoted with incentives such as the existence of a local market for these products, an opportunity to create jobs and generate more revenues in the Groundnut Basin. Moreso, it will enhance the opportunity to empower women, especially with the promotion of handcrafted trituration techniques [14]. Groundnut products such as oil sell well in international markets; however, sales of edible groundnuts in the domestic market are nearly inexistent, hence the opportunities to further develop this activity. This could be a promising initiative not only because such products are demanded, but also because it is profitable with a possibility of creating many jobs especially in the packaging materials sector.

\section{Conclusions}

Food insecurity remains a major issue for rural communities in Senegal. However, the full exploitation of the groundnut sector, which has already been driving economic growth despite challenges, can actually generate rather good income for these farmers. In fact, the value chain of the groundnut industry, from the procurement of inputs to the sale of finished groundnut products, has a certain number of niches that are largely undeveloped. Each of these niches represents a potential source of income and a way for rural communities to secure their livelihoods. Therefore, taking into account the above-mentioned strategies, the Government should start developing and implementing agricultural policies in order to promote the full operation of unexploited groundnut niches. Such endeavor could start with the creation of an appealing business climate that would enable people to make full use of and derive benefits from a more diversified groundnut industry.

This paper is a mere literature review, and as such, doesn't provide any quantitative analysis information regarding the extent to which the potentials of the Senegalese groundnut industry can be harnessed and the different aspects to consider when implementing the proposed strategies. More research should be carried out to determine the factors that would influence the exploitation of undeveloped groundnut sectors. 


\section{References}

[1] FAO (2007) The State of Food and Agriculture: Paying Farmers for Environmental Services. Agricultural Development Economics Division (ESA), FAO, Rome. www.fao.org/docrep/010/a1200e/a1200e00.htm

[2] Barrett, et al. (2010) Measuring Food Insecurity. Science, 327, 825. http://dx.doi.org/10.1126/science.1182768

[3] Mukete, B. and Monono, S. (2014) Assessing the Impact of Consumer Behaviour on Food Security in South West Cameroon. Journal of Food Security, 2, 87-91.

[4] Coulibaly, A., Wang, L.H. and Mukete, B. (2015) Does Consumer Price Index Affect Food Security in Sub-Saharan Africa? Journal of Food Security, 3, 25-28.

[5] Sunderland, et al. (2011) Forests, Biodiversity and Food Security. International Forestry Review, 13, 259-264.

[6] Pinstrup-Andersen, P. (2009) Agricultural Research and Policy to Achieve Nutrition Goals. Poverty, Insecurity and Development, 1, 353-370.

[7] World Bank (2011) Food Price Hike Drives 44 Million People into Poverty. Press Research No. 2011/333/PREM.

http://web.worldbank.org/WBSITE/EXTERNAL/COUNTRIES/WBEUROPEEXTN/PORT UGALEXTN/0,,contentMDK:22833439 menuPK:309723 pagePK:2865066 piPK:2865079 นtheSitePK:309718,00.html

[8] IFAD (2011) www.ruralpovertyportal.org/country/statistics/tags/senegal

[9] ANSD (2016) Agence Nationale de la Statistique et de la Démographie du Senegal. www.ansd.sn

[10] ClimaTemps.com (2011) Dakar, Senegal Climate Information-ClimateTemp.info, Making Sense of Average Monthly Weather \& Temperature Data with Detailed Climate Graphs That Portray Average Rainfall \& Sunshine Hours. ClimaTemps.com.

[11] Sythud, P., Zhang, Y. and Mukete, B. (2015) Bamboo Resources Utilization: A Potential Source of Income to Support Rural Livelihoods. Applied Ecology and Environmental Sciences, 3, 176-183.

[12] CGIAR (1994) Consultative Group on International Agricultural Research. Encyclopedia of Agricultural Science, 3.

[13] Badiane, C. (2001) TED Case Studies Number 646. http://wwwl.american.edu/TED/senegal-groundnut.htm

[14] Diagne, A (2014) La commercialisation de l'arachide au Sénégal: enjeux, contraintes et perspectives: Une étude dans le bassin arachidier. http://www.bameinfopol.info/IMG/pdf/Memoire_Master2_Arachide_Aminata_Diagne.pdf

[15] Noba, K., Ngom, A., Guèye, M., Bassène, C., Kane, M., Diop, I., Ndoye, F., Mbaye, S., Kane, A. and Tidiane, B. (2014) L'arachide au Sénégal: État des lieux, contraintes et perspectives pour la relance de la filière. $O C L, 21,1-5$.

[16] Cabral, F. (2010) Is the Senegalese Accelerated Growth Strategy Pro-Poor? Journal of Economics and International Finance, 2, 144-155.

[17] Ogen, O. (2007) The Agricultural Sector and Nigeria's Development: Comparative Perspectives from the Brazilian Agro-Industrial Economy 1960-1995. Nabula, 4, 184-194.

[18] Olaoye, A. (2014) Potentials of the Agro Industry towards Achieving Food Security in Nigeria and Other Sub-Saharan African Countries. Journal of Food Security, 2, 3-41.

[19] Gaye, M. (2006) Le secteur arachidier du Sénégal face à son destin: Du mal de l'étatisation 
au remède de la privatisation. OXFAM Dakar 2006.

http://www.bameinfopol.info/IMG/pdf/Memoire_Master2_Arachide_Aminata_Diagne.pdf

[20] Diagana, B. (2008) Réflexions et Perspectives: Agriculture durable et réduction de la pauvreté dans le Bassin arachidier du Sénégal: Résultats du Modèle Analyse Tradeoffs. Institut Scientifique de Recherche Agricole.

http://www.bameinfopol.info/IMG/pdf/Tradeoffs_TOA_2_1_.pdf

[21] Cabral, F. (2010) What Are the Key Factors of Food Insecurity among Senegalese Farmers? African Journal of Food Science, 4, 477-485.

[22] Akobundu, E., Norton, G., Gaye, M. and Bertelsen, M. (1998) Farm-Household Analysis of Policies Affecting Peanut Production in Senegal.

http://crsps.net/wp-content/downloads/Peanut/Inventoried\%208.14/7-1998-4-985.pdf

[23] Caswell, N. (1985) Peasants, peanuts and politics: state marketing in Senegal, 1966-1980. African Studies Centre, Leiden, 45.

[24] LPDA (2003) Lettre de politique de développement de la filière arachide. http://www.hubrural.org/Senegal-Lettre-de-Politique-de,3213.html

[25] Diagana, B. and Kelly, V. (2011) La dévaluation du franc CFA: Quelles perspectives pour une intensification durable de la production agricole dans le bassin arachidier du Sénégal? Note de synthèse USAID. https://ideas.repec.org/p/ags/midips/11351.html

[26] Ndéné, M. (2011) Quand l'arachide tousse au Sénégal, l'économie rurale s'enrhume! http://www.ocl-journal.org/articles/ocl/pdf/2014/02/ocl130020.pdf

[27] FAO (2003) L'évaluation de la dégradation des terres au Sénégal. Projet FAO Land Degradation Assessment. Rapport pré-liminaire, Rome, 59.

[28] Kouadio, L. (2007) Des Interuniversitaires en gestion des risques naturels: Prévision de la production nationale d'arachide au Sénégal à partir du modèle agrométéorologique AMS et du NDVI. ULG-Gembloux, 54 p. http://www.ocl-journal.org/articles/ocl/pdf/2014/02/ocl130020.pdf

[29] Delgado, C. and Jammeh, S. (Eds.) (1991) The Political Economy of Senegal under Structural Adjustment. Praeger Publishers, New York.

[30] Badiane, O. and Kinteh, S. (1994) Trade Pessimism and Regionalism in African Countries: The Case of Groundnut Exporters. http://ebrary.ifpri.org/utils/getfile/collection/p15738coll2/id/125536/filename/125567.pdf

[31] Youm, P. (1991) The Economy since Independence. The Political Economy of Senegal under Structural Adjustment. Praeger Press, New York, 21-30.

[32] Faye, A. (2012) Présentation de la chaîne de valeur arachide. CEPOD, 24 p. http://www.cepod.gouv.sn/sites/default/files/La\%20chaine\%20de\%20valeur\%20arachide.pdf

[33] USGS (2012) United States Geological Survey. Famine Early Warning Systems NetworkInforming Climate Change Adaptation Series. A Climate Trend Analysis of Senegal. https://pubs.usgs.gov/fs/2012/3123/FS12-3123.pdf

[34] Hoerling, M., Hurrell, J., Eischeid, J. and Phillips, A. (2006) Detection and Attribution of Twentieth-Century Northern and Southern African Rainfall Change. Journal of Climatology, 19, 3989-4008. http://dx.doi.org/10.1175/JCLI3842.1

[35] Funk, C., Michaelsen, J. and Marshall, M. (2012) Mapping Recent Decadal Climate Variations in Precipitation and Temperature across Eastern Africa and the Sahel. In: Wardlow, B., Anderson, M. and Verdin, J., Eds., Remote Sensing of Drought-Innovative Monitoring Approaches, Taylor and Francis, London, Chapter 14, 25 p.

[36] CIA (2011) Central Intelligence Agency. The World Factbook. 
https://www.cia.gov/library/publications/the-world-factbook/geos/sg.html

[37] FAO (2011) Food Security Data and Definitions. FAO.

http://www.fao.org/economic/ess/ess-fs/fsdata/ess-fadata/en/

[38] UN-HABITAT and UNEP (2010) The State of African Cities: UNEP/UN-HABITAT, Nairobi. file:///F:/3034_alt.pdf

[39] Niang, I. (1990) Responses to the Impacts of Greenhouse Induced Sea Level Rise on Senegal. In: Titus, J.G., Ed., Changing Climate and the Coast, US Environmental Protection Agency, Washington DC, Vol. 2, 67-87.

[40] Brown, S., Kebede, A. and Nicholls, J. (2011) Sea-Level Rise and Impacts in Africa, 20002100 .

http://www.unep.org/climatechange/adaptation/Portals/133/documents/AdaptCost/9\%20S ea\%20Level\%20Rise\%20Report\%20Jan\%202010.pdf

[41] Bonnefond, P. and Couty, P. (1988) Senegal: Passé et avenir d'une crise agricole. Revue Tiers Monde, 29, 319-340. http://dx.doi.org/10.3406/tiers.1988.3542 http://www.persee.fr/doc/tiers_0040-7356_1988_num_29_114_3542

[42] Coote, B. and Lequesne, C. (1996) The Trade Gap: Poverty and the Global Commodity Markets. New Edition, Oxfam, London.

[43] Janowiak, J. (1988) An Investigation of Interannual Rainfall Variability in Africa. Journal of Climate, 1, 240-255. http://research.jisao.washington.edu/data_sets/sahel/ http://dx.doi.org/10.1175/1520-0442(1988)001<0240:AIOIRV>2.0.CO;2

[44] Gaye, M. (2013) Le Sénégal pourra-t-il revivre sa belle économie arachidière, Communication personnelle. 18e Mardi du BAME, Thème: la filière arachidière au Sénégal, 27 Août 2013, ISRA, Dakar, Communication Orale.

[45] Diouf, M. (2013) Reconstitution du capital semencier de l'arachide: Intérêt, enjeux et perspectives. 18e Mardi du BAME, Thème: la filière arachidière au Sénégal, 27 Août 2013, ISRA, Dakar, Communication orale.

\section{Submit or recommend next manuscript to OALib Journal and we will provide best} service for you:

- Publication frequency: Monthly

- 9 subject areas of science, technology and medicine

- Fair and rigorous peer-review system

- Fast publication process

- Article promotion in various social networking sites (LinkedIn, Facebook, Twitter, etc.)

- Maximum dissemination of your research work

Submit Your Paper Online: Click Here to Submit

Contact Us: service@oalib.com 